\title{
Genetic Variability, Heritability and Genetic Advance in Bread Wheat [Triticum aestivum L.]
}

\author{
Upasna Mishra*, A.K. Sharma and Shailja Chauhan \\ Department of Genetics and Plant Breeding, Rajmata Vijayaraje Scindia Krishi \\ VishwaVidhyalaya, Gwalior, Madhya Pradesh, India - 474005 \\ *Corresponding author
}

\section{Keywords}

Genetic variability, Heritability, Genetic advance, Bread wheat

Article Info

Accepted:

17 June 2019

Available Online:

10 July 2019

\section{A B S T R A C T}

An experiment was conducted in a randomized complete block design with two replications at experimental area of Research Farm, College of Agriculture, Gwalior, (M.P.) during 2014-2015. The study was undertaken to inheritance of grain yield and its components in thirty six wheat genotypes. Analysis of variance revealed that genotypes were significantly differed for all characters and suggested considerable variability for all yield and its attributing characters in the present material. Among genotypes tested, HI 1610 seems to be the best, because, it is highest yielder, early flowering, early maturing, and bold grain size and dwarf.Almost equal magnitude of GCV and PCV showed for days to heading, 1000 grain weight and days to maturity indicating that these characters are less influenced by the environment while grain yield and plant height exhibited high value of PCV over its GCV value, indicating relatively large amount of variation for these characters was due to environment alone. The Higher heritability was observed for days to heading, 1000 grain weight and plant height. High heritability coupled with high genetic advance recorded for traits 1000 grain weight, plant height, days to heading and grain yield and that these characters are governed by additive gene effects; a directional selection for these traits would be more effective for desired genetic improvement.

\section{Introduction}

The common bread Wheat (Triticum aestivum L.) is the most important cereal crop in India and stands only second largest produce of wheat in the world after china. It is the largest staple food crop of about two billion people (36\% of the world population) and an important commodity on the world grain commerce. Worldwide, wheat provides nearly $55 \%$ of the carbohydrates and $20 \%$ of the food calories consumed globally (Breiman and Graur, 1995). Sakamura reported the chromosome number sets (genomes) for each commonly recognized type. He separated wheat into three groups viz. diploids $(2 n=14)$, tetraploids $(2 n=28)$ and hexaploids $(2 n=42)$ chromosomes. Major cultivated species of wheat include: Triticum aestivum, which is a hexaploid species and is widely cultivated in the world; Triticum durum, the only tetraploid form of wheat widely used today, and the 
second most widely cultivated wheat; Triticum monococcum, a diploid species with wild and cultivated variants; Triticum dicoccum, a tetraploid species. These earliest cultivated forms were diploid (genome AA) (einkorn) and tetraploid (genome AABB) (emmer) wheat's and their genetic relationships indicate that they originated from the south-eastern part of Turkey (Heun et al., 1997; Nesbitt, 1998; Dubcovsky and Dvorak, 2007).

\section{Materials and Methods}

An experiment was conducted in a randomized complete block design with two replications at experimental area of Research Farm, College of Agriculture, Gwalior, (M.P.) during 2014-2015. The experimental material consisted of 36 wheat genotypes. The sowing was done by dibbling seeds in rows with spacing of $20 \mathrm{~cm}$ apart and 4-6 cm within row on November 21 (Timely sown environment 2014-15). The recommended agronomical practices and plant protection measures were followed for the successful raising of the crop. Observations were recorded on randomly selected 5 plants for grain yield and different yield contributing traits viz., Plant height $(\mathrm{cm})$, Days to heading, 1000 grain weight $(\mathrm{g})$, Grain yield (kg/plot), Days to maturity in each plot. The phenotypic and genotypic coefficients of variation which measure the magnitude of phenotypic and genotypic variation present in a particular character were computed by the formulae given by Burton and De Vane (1953). The coefficient of variation was proposed by Sivasubramanian and MadhavaMenon (1973). The estimation of expected genetic advance from selection $G(s)$, was obtained by the formula suggested by Robinson, Comstock, and Harvey (1949) and Genetic advance as percent of mean was classified as low, moderate and high by Johnson et al., (1955). Heritability in per cent in broad sense was estimated by Singh and Choudhary (1977).
Heritability values are categorized as low, moderate and high by Robinson et al., (1949).

\section{Results and Discussion}

Analysis of variance revealed that genotypes were significant for all 5 characters viz., plant height, days to heading, 1000 grain weight, days to maturity and grain yield. Present finding are similar with earlier reports of Zare et al., (2015) and Aycicek and Yildirim (2006).

Mean performance revealed that out of 15 genotypes viz., HI 1610 showed significant highest grain yield (2779 g) along with significantly early in days to heading (87.50), dwarf plant height and bolder seed size as reflected by 1000 grain weight. DBW 170 was recorded significantly bolder seed size as reflected by 1000 grain weight $(36.42 \mathrm{~g})$ with grain yield. GW 468 was recorded significantly dwarf plant height and late to maturity with grain yield. HI 1607 showed significantly late to maturity with grain yield. UAS 370 showed significantly HI 1909 showed significantly bolder seed size as reflected by 1000 grain weight and late to maturity with grain yield. RVW 4232 showed significantly late to maturity with grain yield. GW 473 showed significantly showed significantly late to maturity with grain yield. AKAW 4798 showed significantly higher grain yield. MACS 6668 showed significantly bolder seed size as reflected by 1000 grain weight with grain yield. PVW 732 late to maturity with grain yield. GW 469 showed significantly dwarf plant height, late to maturity with grain yield. GW 470 showed significantly late to maturity with grain yield. CG 1016 showed significantly dwarf plant height and bolder seed size as reflected by 1000 grain weight, late to maturity with grain yield and HI $1544 \mathrm{C}$ showed significantly dwarf plant height and late to maturity with grain yield. Present finding are confirmed with Bhutto et al., (2016). 
Table.1 Extent of genetic parameters for yield and its attributing characters in wheat genotypes.




The estimation of phenotypic and genotypic coefficient of variation is presented in Table 1, phenotypic coefficient of variation (PCV) was moderate for Grain yield (17.45\%). However, it was low for the traits 1000 grain weight $(9.70 \%)$, plant height $(8.39 \%)$, days to heading $(3.86 \%)$, days to maturity $(1.84 \%)$.The moderate genotypic coefficient of variation (GCV) was observed for the grain yield $(10.46 \%)$; it was low for rest of the traits, that is, 1000 grain weight $(8.21 \%)$, plant height $(6.50 \%)$, days to heading $(3.72 \%)$ and days to maturity (1.39\%).Almost equal magnitude of GCV and PCV showed for days to heading, 1000 grain weight and days to maturity indicating that these characters are less influenced by the environment while grain yield and plant height exhibited high value of PCV over its GCV value, indicating large amount of variation for these characters was due to environment only. Present finding are in confirmation with Degewione et al., (2013), Maurya et al., (2014) and Yadav et al., (2014).

The estimates of broad-sense heritability have been presented in Table 1. The Highest heritability was observed for days to heading $(92.95 \%)$ followed by 1000 grain weight $(71.65 \%)$ and plant height $(60.05 \%)$; while it was moderate for days to maturity $(56.68 \%)$ and grain yield (35.91\%). Present finding conformed to those of Ali et al., (2008), Chaudhary et al., (2015), Deoraj et al., (2016) and Shashikala et al., (2012).

The estimates of expected genetic advance (Table 1) was found to be highest (though moderate) for the trait 1000 grain weight $(14.31 \%)$, followed by that of grain yield $(12.91 \%)$ and plant height $(10.38 \%)$. For rest of the traits it was low; such that for days to heading it was $7.37 \%$ and for days to maturity it was least $2.15 \%$.High heritability estimates coupled with high genetic advance were found for 1000 grain weight, plant height, days to heading and grain yield, thereby, suggested effectiveness of selection for the improvement of these traits. These findings are confirmed with Deoraj et al., (2016) and Kabir et al., (2015).

\section{References}

Ali yousaf, Atta B. M., Akhter J., Monneveux P. and Zahid L. (2008).Genetic variability, association and diversity Studies in wheat (Triticum aestivum 1.) Germplasm. Pak. J. Bot., 40(5): 20872097.

Bhutto, A.H., Rajpar, A.A., Kalhoro, S.A., Ali, A., Kalhoro, F.A., Ahmed, M., Ahmed, S. and Kalhoro, N.A. (2016) Correlation and Regression Analysis for Yield Traits in Wheat (Triticum aestivum L.)Genotypes. Nat. Scie. 8: 96-104.

Breiman A, Graur D (1995). Wheat evolution. Israel J. Plant Sci. 43:85-98.

Burton, G. M. and DeVane, E. M. 1953. Estimating heritability in tall Fescue from replication clonal material. Agron. J., 45: 478-481.

Burton, G.W., 1952. Quantitative inheritance in grasses. Proc. Int. Grassland Congr., 1: 277-283.

Choudhary RC, Sharma NK, Kumar R. and Kumar M. (2015). Genetic variability, heritability and genetic advance in Wheat under different normal and heat stressed environments. Elect. J. Pl. Breed., 6(4): 1082-1087.

Degewione A., Dejene T. and Mohammed S. (2013). Genetic variability and traits association in bread wheat (Triticum aestivum L.) genotypes. Int. Res. J. Agric. Sci.1 (2):19-29.

Deoraj M. G., Dahat D. V., Rajput H. J. and Wakale M. B. (2016) Studies on Variability in Wheat (Triticum aestivum Linn.). Inter. Res. J. Multidisc. Stu., 2(2): 1-4. 
Dubcovsky J, Dvorak J. Genome plasticity: a key factor in the success of polyploid wheat under domestication, Science, 2007, vol. 316 (pg. 1862-1866)

Falconer, D.S. and T.F.C. Mackay, 1996. Introduction to Quantitative Genetics. 4th Edn., Benjamin Cummings, London, UK., Pages: 464.

Hanson CH, Rabinson HE, Comstock RE (1956) Biometrical studies of yield is segregating population of Korean lespedeza. Agron J 48: 268-272.

Johnson, H.W., H.F. Robinson and R.E. Comstock, 1955. Estimation of genetic and environmental variability in soybeans. Agron. J., 47: 314-318.

Kabir ML., Hasanuzzaman M., Rabby MK., Haque MR., Rahman MW. (2015). Selection of parents for hybridization in wheat (Triticum aestivum L.). Int. J. Agri. \& Agri. R. 7(3): 76-84.

Manfred Heun, Ralf Schäfer-Pregl, Dieter Klawan, Renato Castagna, Monica Accerbi, Basilio Borghi, Francesco Salamin (1997). Site of Einkorn Wheat Domestication Identified by DNA Fingerprinting. Science Vol. 278, pp. 1312-1314

Maurya M., Chaurasia A. K., Kumar A., Maurya C. L., Bara B. M., Kumar M., Rai P.K. (2014). Genetic variability for seed yield and its component characters in wheat (Triticum aestivum L.) under Allahabad Agro-Climatic Conditions. Int. J. Rec. Dev. Engg. \& Tech. 2(4):124-126.

Nesbitt M. Where was einkorn wheat domesticated? Trends in Plant Science, 1998, vol. 3: 1360-1385.

Robinson, H. F.; Comstock, R. E. and Harvey, P. H. (1949). Estimation of heritability and the degree of dominance in corn. Agron. J., 41: 353-359.

Sakamura T (1918) Kurze Mitteilunguber die Chromosomenzahlen und die Verwandt-schaftsverhaltnisse der Triticum-Arten. Bot Mag (Tokyo) 32:150-153

Shashikala S. Kolakar, Hanchinal R.R. and Nadukeri S. (2012). Assessment of genetic variability in wheat genotypes. Adv. Res. J. Crop Improv.; 3(2): 114117.

Singh, B.D., 1990. Plant Breeding: Principles and Methods. Kalyani Publishers, New Delhi, India.

Sivasubramanian, S and Madhava Menon, P. 1973. Genotypic and phenotypic variability in rice. Madras Agric. J. 60(9-12): 1093-96.

Yadav S. K., Singh A. K., Baghel S. S., M. Jarman and Singh A. K. (2014). Assessment of Genetic variability and Diversity for Yield and its Contributing Traits among CIMMYT Based Wheat Germplasm. J. Wheat Res. 6(2): 154159.

Zare, M., Parvizi, H., Sharafzadeh, S.andAzarpanah, A. (2015). Evaluation of wheat cultivars under various irrigation methods based on same agronomic and physiological traits. $J$. glob. Bioscie. 4(2): 1327-1334.

\section{How to cite this article:}

Upasna Mishra, A.K. Sharma and Shailja Chauhan. 2019. Genetic Variability, Heritability and Genetic Advance in Bread Wheat [Triticum aestivum L.]. Int.J.Curr.Microbiol.App.Sci. 8(07): 2311-2315. doi: https://doi.org/10.20546/ijcmas.2019.807.282 